\title{
Mutu Kimia Minyak dan Komponen Aktif Minyak Buah Merah (Pandanus conoideus L.) yang Dinetralisasi Menggunakan Larutan Alkali
}

\section{Oil Quality and Active Components Content of Refined Red Fruit (Pandanus conoideus L.) Oil Using Alkaline Solution}

\author{
Budi Santoso $^{1)}$, Zita L. Sarungallo ${ }^{* 1)}$, Risma U. Situngkir ${ }^{1)}$, Mathelda K. Roreng ${ }^{1)}$, \\ Meike M. Lisangan ${ }^{1)}$ dan Venny Murni ${ }^{1)}$ \\ 1) Jurusan Teknologi Pertanian, Fakultas Teknologi Pertanian. Universitas Papua (UNIPA), Jl. Gunung Salju \\ Amban Manokwari-98314, Papua Barat. \\ *Email korespondensi: zlsarungallo@yahoo.com
}

\begin{abstract}
Purification of crude oil through the degumming and neutralization step is intended to remove undesirable unwanted components such as gums and free fatty acids (FFA). This study aims was to determine the quality of netralized red fruit (Pandanus conoideus L.) oil (RFO) with an alkaline solutions. The process of neutralization of degumed RFO was conducted by using three concentration of $\mathrm{NaOH}$ solution $(0.8 \mathrm{~N}, 1 \mathrm{~N}$ and 1.25N), with oil: alkali: water ratio was 5: $1: 1$ and sevent time washing. Quality parameters of neutralized RFOs tested included yield, free fatty acid (FFA), peroxide number, total carotenoid and tocopherol. The results of this study indicated that the yields of neutralized RFO's ranged from 40-54\%. The FFA levels of degummed RFO (1.15\%) could be lowered to $0.31 \%$ by netralization. The use of $\mathrm{NaOH}$ solution with higher normality tends to decrease the FFA levels of RFO, but did not affect peroxide numbers content. Total carotenoid and tocopherol content of neutralized RFOs ranged from 6467-6859 ppm and 2012-2212 ppm, respectively, and it tends to be higher than crude oil or degumed RFO. Overall, the neutralization process can improve the quality of RFO.
\end{abstract}

Keywords: quality of oil, red fruit (Pandanus conoideus L.), alkali solution, neutralization

\begin{abstract}
Abstrak
Pemurnian minyak kasar melalui tahap degumming dan netralisasi dimaksud untuk menghilangkan komponen tidak murni yang tidak diinginkan seperti gum dan asam lemak bebas (ALB). Penelitian ini bertujuan untuk mengetahui mutu dan kandungan aktif minyak buah merah (Pandanus conoideus L.) hasil netralisasi secara alkali. Proses netralisasi minyak buah merah hasil degumming dilakukan menggunakan larutan alkali dengan 3 konsentrasi larutan $\mathrm{NaOH}$ yaitu $0,8 \mathrm{~N}, 1 \mathrm{~N}$ dan $1,25 \mathrm{~N}$, dengan rasio minyak: alkali: air pencucian, masing-masing 5:1:1, dengan tujuh kali pencucian. Parameter mutu minyak buah merah hasil netralisasi (MBMN) yang diuji meliputi rendemen, ALB, bilangan peroksida, total karotenoid dan tokoferol. Hasil penelitian ini menunjukkan bahwa rendemen MBMN berkisar 40-54\%. Kadar ALB minyak degumming (1,15\%) dapat diturunkan menjadi $0,31 \%$ pada konsentrasi $\mathrm{NaOH} 1,25 \mathrm{~N}$. Terdapat kecenderungan semakin tinggi normalitas larutan alkali yang digunakan semakin rendah kadar ALB yang dihasilkan, namun tidak mempengaruhi bilangan peroksida sekitar 0,4 meq/kg. Kandungan total karotenoid dan tokoferol MBMN berturut-turut 6467$6859 \mathrm{ppm}$ and 2012-2212 ppm, lebih tinggi dibandingkan minyak kasar (MBMK) maupun hasil degumming (MBMD). Secara keseluruan proses netralisasi dapat meningkatkan mutu minyak buah merah.
\end{abstract}

Kata Kunci: mutu minyak, buah merah (Pandanus conoideus L.), degumming, dan netralisasi. 


\section{PENDAHULUAN}

Hasil ekstraksi buah merah (Pandanus conoideus L.) merupakan minyak kasar yang mengandung komponen non-trigliserida (fosfolipid atau komplek protein-lemak dan karbohidrat yang bersifat lengket seperti getah dan lendir (gum), pigmen, logam berat, dan asam lemak bebas) sehingga mempengaruhi cita-rasa dan masa simpan minyak. Pemurnian ditujukan untuk mengeluarkan komponen yang tidak diinginkan dengan meminimalkan pengaruh negatif yang mungkin terjadi dan kehilangan komponen yang diinginkan pada minyak (Greyt dan Kellens, 2005). Pemurnian minyak nabati kasar pada umumnya meliputi degumming, netralisasi, bleaching dan deodorisasi (Lin dan Koseoglu, 2005).

Proses degumming dimaksud untuk menghilangkan getah atau lendir yang terdiri dari fosfolipid, protein, residu, dan karbohidrat, tanpa mengurangi jumlah asam lemak bebas (ALB) dalam minyak. Degumming dapat dilakukan dengan berbagai cara, namun penggunaan asam terbukti efektif dalam biaya dan banyak variasi yang telah dikembangkan untuk meningkatkan konsistensi hasilnya (Anderson, 2005). $\begin{array}{llll}\text { Degumming menggunakan } & 0,2 \% & \mathrm{H}_{2} \mathrm{PO}_{4}\end{array}$ (Murtiningrum, 2004), 0,2-2\% asam sitrat dan $2 \%$ asam fosfat (Sirait $d k k .$, 2006) efektif menurunkan kadar fosfor, namun tidak mengurangi kadar ALB minyak buah merah. Oleh karena itu diperlukan tahap netralisasi minyak untuk memisahkan ALB yang merupakan hasil hidrolisis dan oksidasi akibat aktivitas enzim, mikroba, air dan oksigen selama pascapanen buah. ALB berperan dalam pembentukan flavor tengik sehingga mempengaruhi stabilitas minyak selama penyimpanan.

Netralisasi secara kimia dengan alkali $(\mathrm{NaOH})$ paling banyak digunakan industri karena lebih murah dan efisien dalam mereduksi ALB minyak kasar (Bhosle dan Subramanian, 2005). Alkali yang direaksikan dengan ALB akan membentuk sabun. Sabun yang terbentuk juga dapat membantu pemisahan kotoran seperti fosfatida dan protein dengan cara membentuk emulsi, yang dapat dikeluarkan dengan cara pencucian dengan air panas $10-15 \%$ pada suhu $80-90^{\circ} \mathrm{C}$ untuk melarutkan sabun, dan dilanjutkan dengan pemisahan air sabun secara sentrifugasi. Minyak kemudian dikeringkan pada vakum pengering dan menghasilkan minyak semi-refined (netralized oil) (Ketaren 1986; Chu dan Hwang, 2002; Lin dan Koseoglu, 2005). Murtiningrum (2004) melaporkan bahwa netralisasi minyak buah merah hasil degumming secara alkali dapat mereduksi ALB dari 16,17\% menjadi 1,4\%, namun pengaruhnya terhadap komponen aktifnya tidak dilaporkan. Sehingga dalam penelitian ini dilakukan optimasi kadar larutan $\mathrm{NaOH}$ yang tepat untuk menghasilkan minyak murni dengan kadar ALB yang memenuhi persyaratan minyak goreng yaitu $0,3 \%$ (SNI, 2002). Tujuan penelitian ini adalah untuk menentukan mutu dan kandungan aktif minyak buah merah hasil netralisasi secara alkali.

\section{METODOLOGI}

\section{Bahan dan alat}

Bahan baku utama yang digunakan dalam penelitian ini adalah minyak buah merah yang diekstrak dengan cara basah (wet rendering), asam sitrat (merk Koepoe-koepoe) dan $\mathrm{NaOH}$ (Merck). Bahan kimia untuk analisis kimia dengan analytical grade yaitu etanol 95\% (JT Bekker), indikator fenolftalin (Merck), kalium hidroksida (Merck), asam asetat glasia (Merck), kloroform (JT Bekker), kalium iodide (Merck), natrium sulfat(Merck), pati (Merck), butylated hydroxytoluene (Merck), heksan (JT Bekker), toluene (Merck), bipiridin (Merck), dan $\mathrm{FeCl}_{3} \cdot 6 \cdot \mathrm{H}_{2} \mathrm{O}$ (Merck).

Peralatan yang digunakan untuk analisis minyak buah merah antara lain timbangan analitik satuan terkecil $0,0001 \mathrm{~g}$ (Radwag, WAS 220/C/2), timbangan digital satuan terkecil 0,001 g (Ohaus GT 410), oven (Memmert, suhu maks. $250^{\circ} \mathrm{C}$ ), hot plate (Gerhardt, MAG-H), vortex (HeidolphReax), water bath (Imperial IV, LAB-LINE), sentrifuse (Hettich EBA III, alat titrasi, spektrofotometer (Shimadzu UV-2450, Kyoto, Jepang), serta peralatan gelas lainnya.

\section{Metode Penelitian}

Penelitian ini menggunakan Rancangan Acak Lengkap (RAL) yang terdiri dari lima perlakuan, yaitu minyak buah merah kasar, minyak buah merah degumming, dan tiga perlakuan minyak buah netralisasi (menggunakan 0,8 N NaOH; 1,0 N NaOH; dan $1,25 \mathrm{~N} \mathrm{NaOH}$ ), dan masing-masing perlakuan diulang sebanyak tiga kali. 
Proses degumming minyak buah merah kasar

Proses degumming minyak buah merah diawali dengan pemanasan minyak kasar buah merah sebanyak $250 \mathrm{ml}$ dalam penangas suhu $60{ }^{\circ} \mathrm{C}$, penambahan asam sitrat $0-2 \%$ dan diaduk selama 5 menit. Selanjutnya penambahan air ( $\mathrm{pH}$ netral) dengan perbandingan 1:2 dan diaduk menggunakan magnetic stirrer selama 5 menit. Selanjutnya tahapan pemisahan minyak yang didegumming dengan air dan gum menggunakan sentrifugasi, selama 5 menit. Minyak hasil degumming dipisahkan selanjutnya dinetralkan kembali menggunakan air dengan perbandingan 1:2, sampai air pencuciannya netral ( $\mathrm{pH} 7$ ), sehingga dihasilkan minyak buah merah degumming (MBMD) (Sarungallo $d k k ., 2018)$

Proses netralisasi minyak deguming buah merah hasil (MBMD)

Proses netralisasi MBMD dilakukan dengan menambahkan larutan $\mathrm{NaOH}$ dengan konsentrasi $0,25 \%, 0,5 \%$, dan 0,6\%, kemudian dilakukan pengadukan selama 5 menit hingga menimbulkan busa. Selanjutnya ditambahkan air masing-masing dengan perbandingan 1:1 dan diaduk selama 5 menit dan disentrifugasi selama 10 menit. Minyak yang diperoleh selanjutnya dicuci dengan air dingin dengan perbandingan air dan minyak sebanyak 1:1, setelah diaduk disentrifugasi; dan dilanjutkan dengan proses pencucian. Minyak buah merah hasil netralisasi (MBMN) selanjutnya dianalisa terhadap kadar air, ALB, bilangan peroksida, total karotenoid dan total tokoferol. Pelaksanaan tahapan penelitian ini menggunakan RAL dengan 3 ulangan.

\section{Analisis mutu kimia}

Mutu kimia minyak buah merah dianalisis terhadap rendemen minyak buah merah dengan metode gravitasi. Sedangkan kadar ALB ditentukan berdasarkan metode titrasi dan bilangan peroksida menggunakan metode asam asetat-chloroform (AOCS, 2003).

\section{Analisis total karotenoid}

Pengukuran total karotenoid menggunakan metode Knockaert $d k k$. (2012) dengan sedikit modifikasi. Sebanyak 0,01 g minyak buah merah, ditambahkan $0,1 \%$ butylated hydroxytoluene (BHT) dan heksan dalam labu ukur $10 \mathrm{ml}$ sampai tanda tera dan divortek. Selanjutnya absorbansi diukur dengan spektrofotometer pada panjang gelombang $470 \mathrm{~nm}$ dengan menggunakan heksan yang ditambahkan $0,1 \%$ BHT sebagai blanko. Total karotenoid dihitung menggunakan rumus berikut:

$$
\begin{aligned}
& \text { Konsentrasi karotenoid }\left(\frac{\mathrm{mg}}{\mathrm{kg}}\right) \\
& \qquad=\frac{\mathrm{A} \times \text { volume }\left(\mathrm{ml} \times 10^{4}\right)}{\mathrm{E}_{1 \mathrm{~cm}}^{1 \%} \mathrm{x} \text { berat sampel }(\mathrm{g})}
\end{aligned}
$$

A adalah absorbansi pada $\lambda$ maksimal, volume adalah total volume larutan sampel, $\mathrm{E}_{1 \mathrm{~cm}}^{1 \%}$ adalah extinction coefficient yaitu 2560 untuk $\beta$-karoten dalam heksan (Hart dan Scott, 1995).

\section{Analisis total tokoferol}

Pengukuran total tokoferol menggunakan metode Wong $d k k$. (1988). Sebanyak $0.01 \mathrm{~g}$ contoh dimasukan dalam labu takar $10 \mathrm{ml}$ dan ditambahkan $5 \mathrm{ml}$ toluen, 3.5 $\mathrm{ml} \mathrm{2,2}$ bipiridin $(0.07 \% \mathrm{w} / \mathrm{v}$ dalam etanol 95\%), $0.5 \mathrm{ml} \mathrm{FeCl} 3.6 . \mathrm{H}_{2} \mathrm{O}(0.2 \%$ w/v dalam etanol 95\%). Larutan ditepatkan sampai $10 \mathrm{ml}$ etanol 95\%, lalu divorteks dan didiamkan selama 10 menit. Absorbansi larutan diukur pada spektrofotometer dengan panjang gelombang $520 \mathrm{~nm}$. Blanko dibuat dengan cara yang sama tanpa sampel. Konsentrasi total tokoferol dihitung berdasarkan kurva standar $\alpha$-tokoferol dibuat dengan cara yang sama pada kisaran 100-1500 ppm dalam toluen, dengan menggunakan persamaan:

$$
\text { Total tokoferol }\left(\frac{\mathrm{mg}}{\mathrm{kg}}\right)=\frac{\mathrm{A}}{\mathrm{MxW}}
$$

$\mathrm{A}=$ absorbansi sample; $\mathrm{M}=$ gradient pada kurva standar; $\mathrm{W}=$ berat sampel $(\mathrm{g})$

\section{Analisis data}

Data hasil analisis minyak buah merah yang diperoleh dianalisis menggunakan statistik deskriptif yang disajikan dalam bentuk tabel dan gambar menggunakan Program Excell 2013 (Microsoft Office 2013 dan Office 365).

\section{HASIL DAN PEMBAHASAN}

\section{Rendemen Minyak Buah Merah Hasil Netralisasi}

Tahapan pemurnian minyak nabati kasar pada umumnya melalui 4 tahapan, yaitu 
degumming, netralisasi, bleaching, dan deodorisasi. Proses degumming dimaksud untuk menghilangkan komponen pengotor minyak yang meliputi getah atau lendir yang terdiri dari fosfolipid, protein, residu, dan karbohidrat, tanpa mengurangi jumlah asam lemak bebas (ALB) dalam minyak (Ketaren, 1997). Degumming dapat dilakukan dengan berbagai cara, namun penggunaan asam terbukti efektif dalam biaya dan banyak variasi yang telah dikembangkan untuk meningkatkan konsistensi hasilnya. Proses degumming minyak buah merah kasar (MBMK) menggunakan asam sitrat $2 \%$ dilaporkan dapat memperpanjang masa simpan minyak yang dihasilkan (Sarungallo $d k k$., 2018). Tahap selanjutnya adalah proses netralisasi untuk menurunkan kadar ALB minyak buah merah hasil degumming (MBMD). Dalam kajian ini proses netralisasi secara kimia menggunakan $\mathrm{NaOH}$ dengan beberapa normalitas yaitu 0,8 $\mathrm{N} ; 1,0 \mathrm{~N} ; 1,25 \mathrm{~N} \mathrm{NaOH}$, yang akan bereaksi dengan ALB minyak membentuk sabun (Bhosle dan Subramanian, 2005).
Rendemen minyak buah merah hasil netralisasi (MBMN) dengan 3 konsentrasi $\mathrm{NaOH}$ berkisar 40-54\%, seperti disajikan pada Gambar 1. Dari gambar tersebut dapat dilihat bahwa rendemen MBMN yang diperoleh dari MBMD cenderung menurun dengan bertambahnya konsentrasi $\mathrm{NaOH}$. Penggunaan larutan alkali $(\mathrm{NaOH})$ dalam proses netralisasi bertujuan untuk mengikat asam lemak bebas melalui reaksi esterifikasi serta dapat pula menghilangkan residu fosfolipid. Dari hasil penelitian ini menunjukkan bahwa rendemen MBMD cenderung menurun dengan meningkatnya larutan $\mathrm{NaOH}$. Hal ini diduga pada konsentrasi $\mathrm{NaOH}$ tinggi maka selain terjadi proses esterifikasi pada asam lemak bebas juga berdampak terhadap tersabunkannya komponen trigliserida. Dijkstra (2013) juga melaporkan bahwa larutan kaustik soda yang dicampurkan dengan minyak pada proses netralisasi alkali akan membentuk sabun (saponifikasi), yang akan terdispersi di dalam fase cair bersamaan dengan fosfolipid, pigmen dan komponen lain sehingga dapat menurunkan rendemen minyak.

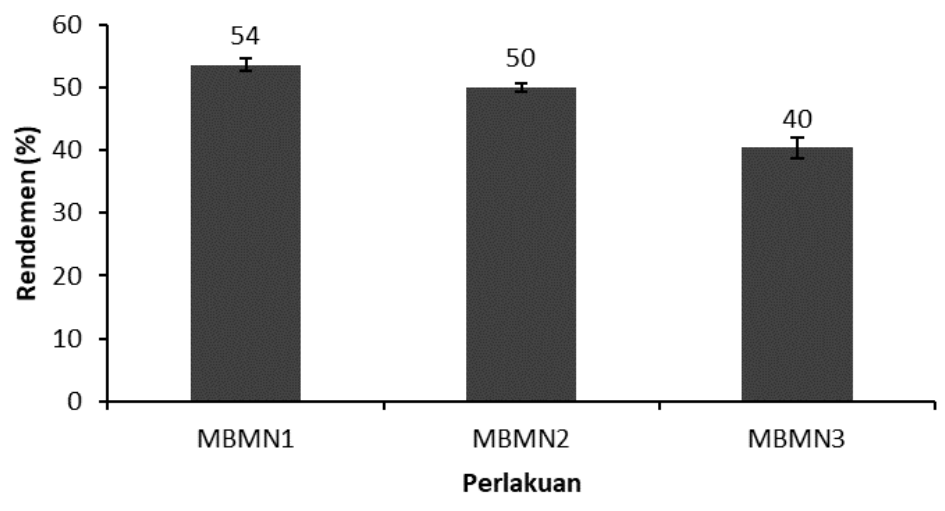

Keterangan: $\mathrm{MBMN}=$ Minyak buah merah hasil netralisasi

$1=\mathrm{NaOH} 0,8 \mathrm{~N} ; 2=\mathrm{NaOH} 1,0 \mathrm{~N} ; 3=\mathrm{NaOH} 1,25 \mathrm{~N}$

Gambar 1. Rendemen minyak buah merah hasil netralisasi

\section{Asam Lemak Bebas}

Keberadaan asam lemak bebas (ALB) merupakan salah satu indikator rusaknya minyak akibat rekasi hidrolisis, yang dapat menginduksi ketengikan minyak selama penyimpanan karena mudah mengalami oksidasi (Bhosle dan Subramanian, 2005). Kadar ALB minyak buah merah hasil dari ke-3 perlakuan netralisasi (MNBM) dengan konsentrasi alkali yaitu $0,8 \mathrm{~N} ; 1,0 \mathrm{~N} ; 1,25 \mathrm{~N}$ $\mathrm{NaOH}$ dibandingkan dengan minyak kasar, minyak degumming buah merah (MDBM) dapat dilihat pada Gambar 2.

Tujuan utama dari proses netralisasi adalah untuk menurunkan kadar ALB yang terdapat di dalam minyak buah merah hasil degumming. Data pada Gambar 2 memperlihatkan bahwa kadar ALB minyak degumming lebih tinggi dari minyak kasar buah merah (MBMK). Hal ini dimungkinkan karena proses degumming menggunakan asam sitrat sehingga mempengaruhi kadar ALB minyak degumming. Wang and Johnson 
(2001) melaporkan kandungan FFA minyak biji gandum meningkat selama degumming, dapat disebabkan karena sisa asam fosfat yang digunakan untuk mengkondisikan minyak

Proses netralisasi dapat menurunkan kadar ALB minyak buah merah hasil degumming (Gambar 2), ALB tersebut dapat membentuk sabun dengan larutan alkali. Kuleasan dan Tekin (2008) juga melaporkan bahwa netralisasi minyak kedelai kasar menggunakan 9,5\% $\mathrm{NaOH}$ dapat menurunkan ALB minyak kasar dari 0,56 menjadi $0,14 \%$.

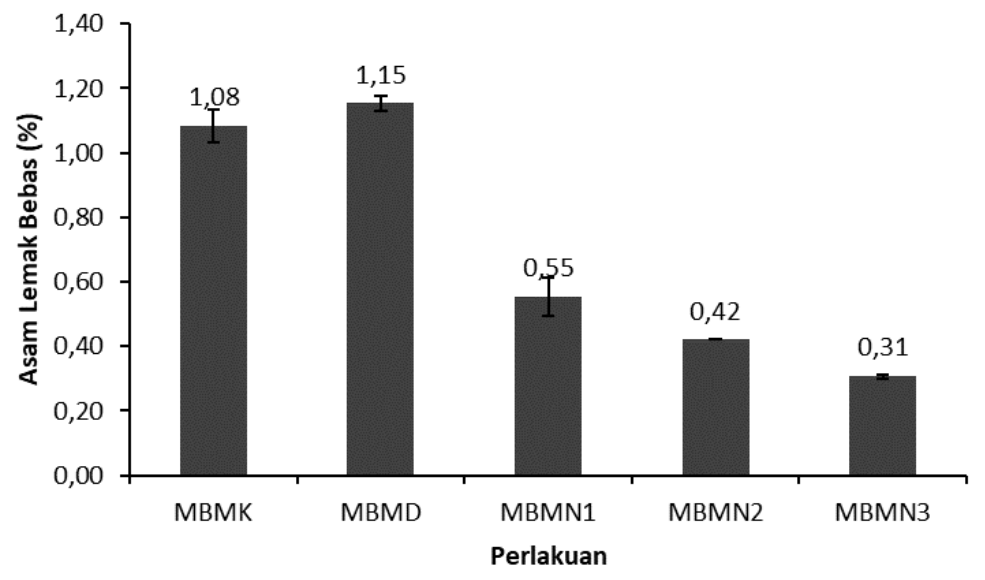

Keterangan: $\quad \mathrm{MBMK}=$ Minyak buah merah kasar; $\mathrm{MBMD}=$ Minyak buah merah degumming; MBMN=Minyak buah merah netralisasi, $1=\mathrm{NaOH} 0,8 \mathrm{~N} ; 2=\mathrm{NaOH} 1,0 \mathrm{~N} ; 3=\mathrm{NaOH} 1,25 \mathrm{~N}$

Gambar 2. Kadar asam lemak bebas minyak buah merah hasil netralisasi

Hasil penelitian pada Gambar 2 juga menunjukkan bahwa peningkatan konsentrasi larutan alkali $(\mathrm{NaOH})$ menyebabkan jumlah ALB minyak buah merah yang tersabunkan semakin tinggi. Konsentrasi $\mathrm{NaOH}$ terbaik dalam tahap netraliasi minyak buah merah ini adalah $1,25 \mathrm{~N}$ karena telah dapat menurunkan ALB hingga $0,31 \%$. Sementara pada konsentrasi $\mathrm{NaOH} 0,8 \mathrm{~N}$ dan $1,0 \mathrm{~N}$ walaupun belum dapat menurunkan hingga batas yang disyaratkan namun kedua konsentrasi tersebut memiliki kadar ALB yang lebih rendah dibandingkan dengan kadar ALB pada minyak buah merah kasar maupun minyak buah merah yang di-degumming. Musyaroh dan Hidayat (2018) melaporkan bahwa peningkatan kadar ALB minyak goreng superworm karena adanya beberapa faktor salah satunya yaitu kadar air yang terdapat pada sampel yang menyebabkan hidrolisis; semakin tinggi konsentrasi larutan kaustik soda $(\mathrm{NaOH})$ maka jumlah asam organik rantai pendek yang bereaksi dengan $\mathrm{NaOH}$ dan membentuk ALB juga semakin rendah.

\section{Bilangan Peroksida}

Bilangan peroksida mengindikasikan kerusakan minyak akibat reaksi oksidasi. Menurut Shahidi dan Zhong (2005) reaksi tersebut merupakan reaksi rantai radikal bebas antara lemak tidak jenuh dan oksigen menghasilkan peroksida, yang dapat dipicu antara lain oleh cahaya, panas, enzim, logam, metaloprotein, dan mikroorganisme. Hasil analisis kadar bilangan peroksida minyak buah merah yang dinetralisasi dibandingkan dengan minyak kasar, minyak buah merah degumming (MBMD) disajikan pada Gambar 3.

Bilangan peroksida minyak buah merah hasil degumming relatif sama dengan minyak kasarnya (Gambar 3). Dengan demikian proses degumming tidak menyebabkan perubahan bilangan peroksida minyak uah merah. Wang dan Johnson (2001), juga melaporkan bahwa nilai peroksida minyak biji gandum kasar tidak dipengaruhi oleh degumming. 


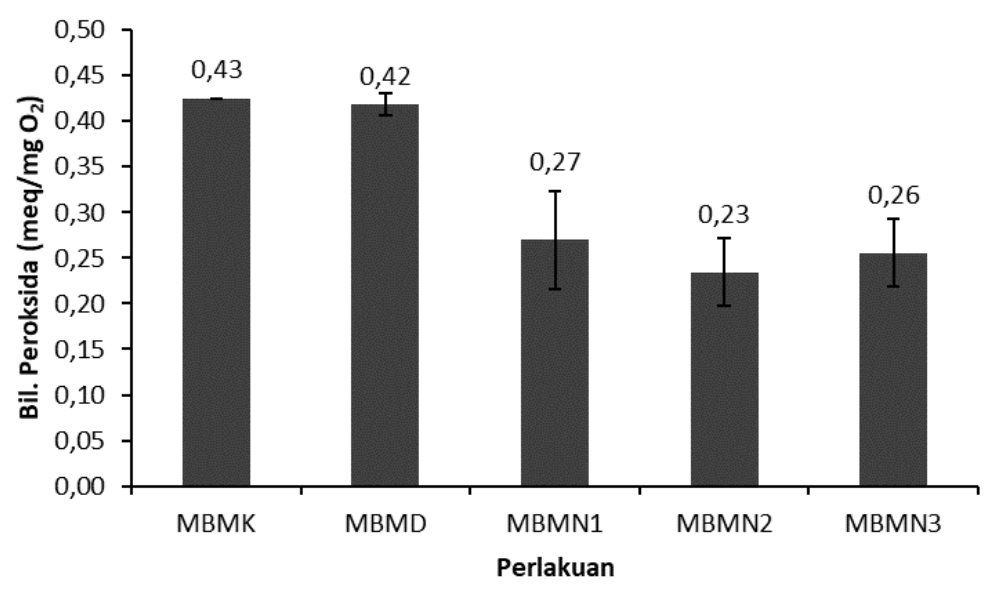

Keterangan: $\quad \mathrm{MBMK}=$ Minyak buah merah kasar; $\mathrm{MBMD}=$ Minyak buah merah degumming; $\mathrm{MBMN}=\mathrm{Minyak}$ buah merah netralisasi, $1=\mathrm{NaOH} 0,8 \mathrm{~N} ; 2=\mathrm{NaOH} 1,0 \mathrm{~N} ; 3=\mathrm{NaOH} 1,25 \mathrm{~N}$

Gambar 3. Kadar bilangan peroksida minyak buah merah hasil netralisasi

Dari data yang diperoleh dapat diketahui bahwa kadar bilangan peroksida pada minyak buah merah kasar dan minyak buah merah yang telah di-degumming sudah cukup rendah, yaitu di bawah dari standar SNI (2002) yang diperbolehkan untuk minyak makan (maks $2 \mathrm{meq} / \mathrm{g} \mathrm{O}_{2}$ sampel). Selanjutnya pada tahap netralisasi, terlihat bahwa peningkatan konsentrasi $\mathrm{NaOH}$ tidak menurunkan kadar bilangan peroksida (Gambar 3).

\section{Total Karotenoid}

Karotenoid merupakan pigmen yang berperan terhadap warna merah pada minyak buah merah, dan berfungsi sebagai aktioksidan yang sangat diperlukan tubuh manusia (Surono $d k k$. , 2008). Data pada Gambar 4 memperlihatkan bahwa proses pemurnian pada tahap degumming relatif tidak mempengaruhi kadar karotenoid minyak buah merah kasar sehingga relatif sama. Namun pada tahap pemurnian selanjutnya yaitu netralisasi cenderung menurunkan kadar komponen aktifnya; karena selama proses tersebut melalui tahapan pencucian minyak buah merah menggunakan air hangat dan sentrifugasi, sehingga memungkinkan terjadinya reaksi isomerisasi dan degradasi karotenoid (Knockaert dkk., 2012; Zeb, 2012). Lebih lanjut Bonnie dan Choo (1999) menjelaskan bahwa jalur degradasi karotenoid umumnya adalah isomerisasi, oksidasi dan fragmentasi molekul karotenoid. Adanya panas dan cahaya menyebabkan isomerisasi karotenoid -trans bentuk menjadi bentuk -cis; sementara cahaya, enzim, logam prooksidasi dan ko-oksidasi dengan lemak tak jenuh menginduksi oksidasi; sedangkan pirolisis terjadi pada pemanasan tinggi dengan melepaskan molekul dengan berat molekul rendah. Murtiningrum et al., (2011) melaporkan bahwa kenaikan kandungan $\beta$-karoten dan $\alpha$-tokoferol minyak buah merah setelah degumming disebabkan karena hilangnya komponen pengotor seperti gum sehingga kadarnya lebih terkonsentrat. 


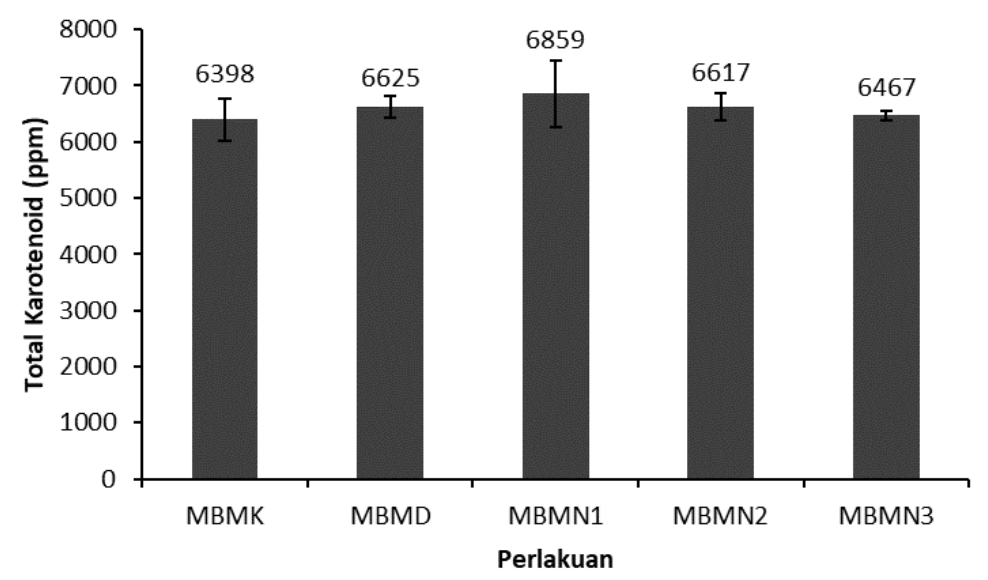

Keterangan: $\quad \mathrm{MBMK}=$ Minyak buah merah kasar; MBMD=Minyak buah merah degumming; MBMN=Minyak buah merah netralisasi, $1=\mathrm{NaOH} 0,8 \mathrm{~N} ; 2=\mathrm{NaOH} 1,0 \mathrm{~N} ; 3=\mathrm{NaOH} 1,25 \mathrm{~N}$

Gambar 4. Total karotenoid minyak buah merah hasil netralisasi dibandingkan dengan minyak kasar, minyak degumming buah merah (MDBM)

\begin{abstract}
Hasil analisis pada Gambar 4 menunjukkan bahwa proses netralisasi menggunakan larutan $\mathrm{NaOH}$ sampai dengan konsentrasi $1,25 \mathrm{~N}$ dapat mempertahankan kadar karotenoid yang ada di dalam minyak buah merah. Hal ini dapat dilihat dari hampir samanya kadar total karotenoid minyak buah merah pada ketiga konsentrasi larutan $\mathrm{NaOH}$ yang digunakan. Fenomena ini disebabkan karena karotenoid tidak ikut tersabunkan oleh larutan $\mathrm{NaOH}$ yang digunakan dalam tahap netralisasi. Sementara kadar total karotenoid minyak buah merah hasil netralisasi secara keseluruhan cenderung lebih tinggi dibandingkan dengan kadar total karotenoid pada minyak buah merah kasar dan minyak buah merah hasil degumming.
\end{abstract}

\section{Total Tokoferol}

Tokoferol merupakan antioksidan alami yang dapat melindungi minyak dari oksidasi, dengan mekanisme seperti antioksidan fenolik lainnya sebagai radical scavenger (Nawar, 1994). Hasil analisis total tokoferol minyak buah merah yang dinetralisasi berkisar antara 2012,33-2212,00 ppm, dibandingkan dengan minyak kasar (2153,67 ppm) dan minyak buah merah degumming (2073,67 ppm) ditampilkan pada Gambar 5. Kadar tokoferol MBMK yang diekstrak secara basah dalam kajian ini (Gambar 5), lebih besar dari kadar tokoferol dari 9 jenis buah merah yang dilaporkan Sarungallo $d k k$ (2015a) sebesar 1060-1728 ppm. Perbedaan kadar tokoferol ini dapat dipengaruhi oleh perbedaan jenis buah merah (Sarungallo $d k k ., 2015 b$ ) dan metode ekstraksi minyak buah merah (Sarungallo $d k k$., 2014). 


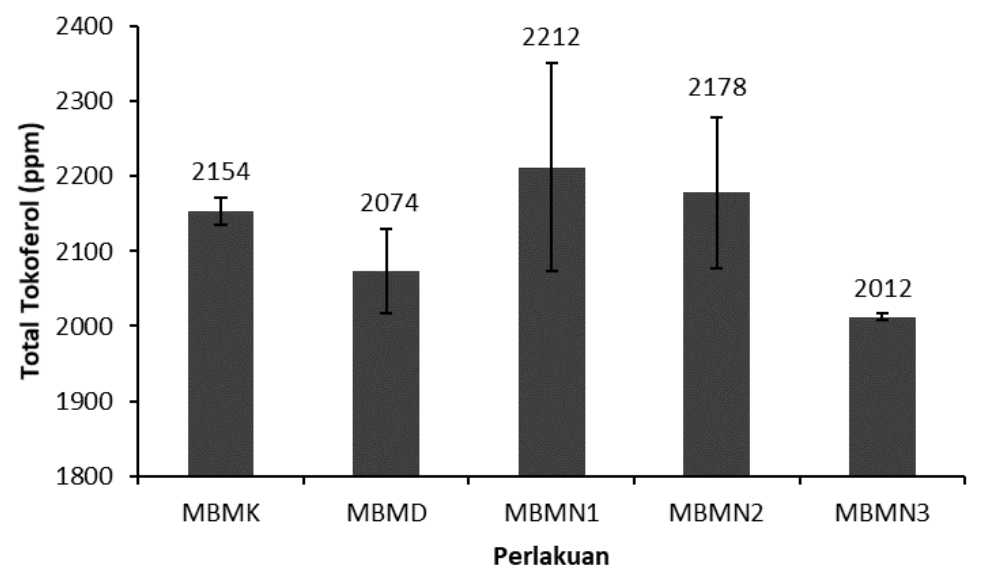

Keterangan: $\quad$ MBMK=Minyak buah merah kasar; MBMD=Minyak buah merah degumming; MBMN=Minyak buah merah netralisasi, $1=\mathrm{NaOH} 0,8 \mathrm{~N} ; 2=\mathrm{NaOH} 1,0 \mathrm{~N} ; 3=\mathrm{NaOH} 1,25 \mathrm{~N}$

Gambar 5. Total tokoferol minyak buah merah hasil netralisasi dibandingkan dengan minyak kasar, minyak degumming buah merah (MBMD)

Berdasarkan data pada Gambar 5 dapat dilihat bahwa kadar total tokoferol pada konsentrasi larutan $\mathrm{NaOH}$ sampai dengan 1,0 $\mathrm{N}$ lebih tinggi dibandingkan minyak kasar dan minyak yang didegumming, namun kemudian kadar tokoferol menurun pada konsentrasi larutan $\mathrm{NaOH}$ meningkat pada $1,25 \mathrm{~N}$. Kecenderungan yang sama seperti pada kadar total karotenoid, tokoferol pun diduga tidak ikut tersabunkan oleh $\mathrm{NaOH}$ dalam tahap netralisasi minyak buah merah. Namun jika dibandingkan dengan kadar total tokoferol pada minyak buah merah kasar dan minyak buah merah hasil degumming seluruhnya lebih tinggi pada minyak buah merah hasil netralisasi. Dengan demikian proses netralisasi minyak buah merah cenderung dapat meningkatkan kadar total tokoferol. Wang dan Johnson (2001) melaporkan bahwa minyak biji gandum kasar tidak berubah secara nyata selama degumming, netralisasi dan bleaching, meskipun $\alpha$-tokoferol berkurang sekitar $14 \%$ setelah dinetralkan. Ditambahkan pula bahwa tokoferol berkurang selama pengolahan minyak kedelai, tetapi pengurangan yang paling nyata adalah selama deodorisasi (Wang dan Johnson, 2001).

\section{KESIMPULAN}

Hasil penelitian ini menunjukkan bahwa rendemen minyak buah merah hasil netralisasi berkisar 40-54\%. Terdapat kecenderungan semakin tinggi normalitas larutan alkali yang digunakan semakin rendah kadar ALB yang dihasilkan, namun tidak mempengaruhi bilangan peroksida sekitar 0,4 meq $/ \mathrm{kg}$. Kadar ALB minyak buah merah hasil degumming $(1,15 \%)$ dapat diturunkan menjadi $0,31 \%$ pada proses netralisasi. Kandungan total karotenoid dan tokoferol minyak buah merah hasil netralisasi berturut-turut 6467-6859 ppm dan 2012-2212 ppm, lebih tinggi dibandingkan minyak kasar maupun minyak hasil degumming. Secara keseluruhan proses netralisasi dapat meningkatkan mutu minyak buah merah.

\section{UCAPAN TERIMA KASIH}

Peneliti mengucapkan terima kasih kepada Kemenristek - Direktorat Jenderal Pendidikan Tinggi atas dana yang diberikan melalui Hibah Penelitian Strategis Nasional tahun 2017, dengan nomor kontrak 059/SP2H/DRPM/II/2016.

\section{DAFTAR PUSTAKA}

Anderson, D., (2005), A Primer on Oils Processing Technology, dalam: F. Shahidi (Ed.). Oil and Fat Products: Processing Technologies. Bailey's Industrial Oil and Fat Products. Sixth Edition Volume 5 Edible John Wiley and Sons, Inc., Publication. New Jersey.

AOCS (American Oil Chemists' Society), (2003), Official Methods and 
Recommended Practices of the AOCS. $5^{\text {th }}$ ed. AOCS. Champaign, Illinois.

Bhosle, B.M., and Subramanian, R., (2005), New approaches in deacidification of edible oil (a review). Journal of Food Engeneering, 69, pp. 481-494.

Chu, Y.H., and Hwang, L.S., (2002), Food Lipid. Dalam: Sikorski, Z.E. (Ed.). Chemical and Functional Properties of Food Components. Second Edition. CRC Press. New York.

Dijkstra, A. J., (2013), Edible Oil Processing from a Patent Perspective. Springer, New York.

Greyt, W.D., and Kellens, M., (2005), Deodorization. Dalam: Shahidi, F. (Ed.). Bailey's Industrial Oil and Fat Products, Sixth Edition, Six Volume Set. John Wiley \& Sons, Inc. New Jersey.

Hart, D.J., and Scott, K.J., (1995), Development and evaluation of an HPLC method for the analysis of carotenoids in foods, and the measurement of the carotenoid content of vegetables and fruits commonly consumed in the UK. Food Chemistry, 54, pp. 101-111.

Ketaren, S., (1986), Pengantar Teknologi Minyak dan Lemak Pangan. UI-Press. Jakarta.

Knockaert, G., Lemmens, L., VanBuggenhout, S., Hendrickx, M., and Van-Loey, A., (2012), Changes in $\beta$ carotene bioaccessibility and concentration during processing of carrot puree. Food Chemistry, 133, pp. 60-67.

Kuleasan, S., and Tekin, A., (2008), Alkaline neutralization of crude soybean oil by various adsorbents. European Journal of Lipid Science and Technology, 110(3), pp. 261-265.

Lin, L., and Koseoglu, S.S., (2005), Membrane Processing of Fats and Oils. Dalam: Shahidi, F. (Ed). Edible Oil and Fat Products: Processing Technologies. Bailey's Industrial Oil and Fat Products. Sixth Edition Volume 5. John Wiley and Sons, Inc., Publication. New Jersey.

Murtiningrum, (2004), Ekstraksi Minyak dengan Metode Wet Rendering dari Buah Merah (Pandanus conoideus L.) dan Pemurnian dengan Filtrasi Membran. Tesis. Program
Pascasarjana. Institut Pertanian Bogor, Bogor.

Murtiningrum, Sarungallo, Z, L. dan Roreng M. K., (2011), Kandungan komponen aktif minyak kasar dan hasil degumming dari buah merah (Pandanus conoideus) yang diekstrak secara tradisional. Dalam: $\mathrm{R}$ I Montolalu, N Andarwulan, FG Ijong, D Tooy, GSS Djarkasi, F. Mentang dan D.M Makapedua (editor). Prosiding Seminar Nasional Perhimpunan Ahli Pangan Indonesia (PATPI) di Manado, Sulawesi Utara. pp. 157-160.

Nawar, W.W., (1996), Lipids. Dalam: Fennema, O.R. (Ed.). Food Chemistry (3rd ed). Marcel Dekker, New York.

Sarungallo, Z. L., Hariyadi, P., Andarwulan, N., dan Purnomo, E. H., (2014), Pengaruh metode ekstraksi terhadap mutu kimia dan komposisi asam lemak minyak buah merah (Pandanus conoideus). Teknologi Industri Pertanian, 24(3), pp. 209-217

Sarungallo, Z. L., Hariyadi, P., Andarwulan, N., dan Purnomo, E. H., (2015a), Analysis of $\alpha$-cryptoxanthin, $\beta$ cryptoxanthin, $\alpha$-carotene, and $\beta$ carotene of Pandanus conoideus oil by high-performance liquid chromatography (HPLC). Procedia Food Science, 3, pp. 231-243.

Sarungallo, Z. L., Hariyadi, P., Andarwulan, N. and Purnomo, E. H., (2015b), Characterization of chemical properties, lipid profile, total phenol and tocopherol content of oils extracted from nine clones of red fruit (Pandanus conoideus). Kasetsart Journal (Nature Science), 49, pp. 237-250.

Sarungallo, Z. L., Santoso, B., Lisangan, M. M., Paiki, S. N. P., Situngkir, R. U., dan Asokawati, E., (2018), Kinetika Perubahan Mutu Minyak Buah Merah (Pandanus conoideus) Hasil Degumming Selama Penyimpanan. Jurnal Aplikasi Teknologi Pangan, 7 (4), pp. 156-162.

Shahidi, F., and Zhong, W., (2005), Lipid Oxidation: Measurement Methods. Dalam: Shahidi, F. (Ed). Edible Oil and Fat Products: Processing Technologies. Bailey's Industrial Oil and Fat Products. Sixth Edition 
Volume 5. John Wiley and Sons, Inc., Publication. New Jersey.

Sirait, D.S., Kusmayadi, D., dan Suryaseca, Y., (2006), Penelitian dan Pengembangan Pemurnian Sederhana Minyak Buah Merah (Pandanus conoideus L). Laporan Penelitian Balai Besar Industri Agro. Badan Penelitian dan Pengembangan Industri. Deartemen Perindustrian Republik Indoneisa. Bogor.

SNI (Standar Nasional Indonesia) 01-29011992., (1992), Badan Standarisasi Nasional. Jakarta.

SNI (Standar Nasional Indonesia) 01-37412002, (2002), Minyak goreng. Badan Standarisasi Nasional. Jakarta.
Surono, I., Endaryanto, T.A., and Nishigaki, T., (2008), Indonesian Biodiversities, from Microbes to Herbal Plants as Potential Functional Foods. Journal of the Faculty of Agriculture Shinshu University, 44(1.2), pp. 23-27.

Wang, T., and Johnson, L. A., (2001), Refining High-Free Fatty Acid Wheat Germ Oil. Journal of the American Oil Chemists' Society, 78(1), pp. 71-76.

Wong, M.L., Timms, R.E., and Goh, E.M., (1988), Colorimetric determination of total tocopherols in palm olein and stearin. Journal of the American Oil Chemists' Society, 65, pp. 258-261. 